March 2002 • NREL/CP-710-31310

\title{
Analyzing Two Federal Building-Integrated Photovoltaic Projects Using ENERGY-10 Simulations
}

\section{Preprint}

A. Walker and D. Balcomb

National Renewable Energy Laboratory

N. Weaver

InterWeaver Consulting

G. Kiss

Kiss+Cathcart Architects

M. Becker-Humphry

Smithsonian Institution

To be presented at the American Society of Mechanical

Engineers Solar 2002

Reno, Nevada

June 15-20, 2002
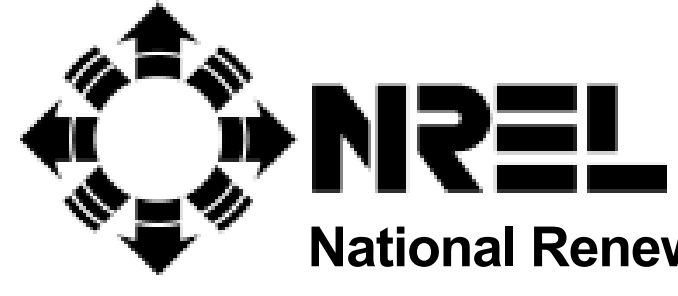

National Renewable Energy Laboratory

1617 Cole Boulevard

Golden, Colorado 80401-3393

NREL is a U.S. Department of Energy Laboratory

Operated by Midwest Research Institute $\bullet$ Battelle $\bullet$ Bechtel

Contract No. DE-AC36-99-G010337 


\section{NOTICE}

The submitted manuscript has been offered by an employee of the Midwest Research Institute (MRI), a contractor of the US Government under Contract No. DE-AC36-99G010337. Accordingly, the US Government and MRI retain a nonexclusive royalty-free license to publish or reproduce the published form of this contribution, or allow others to do so, for US Government purposes.

This report was prepared as an account of work sponsored by an agency of the United States government. Neither the United States government nor any agency thereof, nor any of their employees, makes any warranty, express or implied, or assumes any legal liability or responsibility for the accuracy, completeness, or usefulness of any information, apparatus, product, or process disclosed, or represents that its use would not infringe privately owned rights. Reference herein to any specific commercial product, process, or service by trade name, trademark, manufacturer, or otherwise does not necessarily constitute or imply its endorsement, recommendation, or favoring by the United States government or any agency thereof. The views and opinions of authors expressed herein do not necessarily state or reflect those of the United States government or any agency thereof.

Available electronically at http://www.osti.gov/bridge

Available for a processing fee to U.S. Department of Energy and its contractors, in paper, from:

U.S. Department of Energy

Office of Scientific and Technical Information

P.O. Box 62

Oak Ridge, TN 37831-0062

phone: 865.576.8401

fax: 865.576 .5728

email: reports@adonis.osti.gov

Available for sale to the public, in paper, from:

U.S. Department of Commerce

National Technical Information Service

5285 Port Royal Road

Springfield, VA 22161

phone: 800.553 .6847

fax: 703.605.6900

email: orders@ntis.fedworld.gov

online ordering: http://www.ntis.gov/ordering.htm

Printed on paper containing at least $50 \%$ wastepaper, including $20 \%$ postconsumer waste 


\title{
ANALYZING TWO FEDERAL BUILDING INTEGRATED PHOTOVOLTAICS PROJECTS USING ENERGY-10 SIMULATIONS
}

\author{
Andy Walker, Ph.D., PE \\ National Renewable Energy Laboratory \\ 1617 Cole Blvd. \\ Golden, Colorado 80401-3393 \\ Andy_Walker@nrel.gov
}

\author{
Norm Weaver, PE \\ InterWeaver Consulting \\ PO Box 775444 \\ Steamboat Springs, Colorado 80477 \\ N_weaver@interwvr.com
}

\author{
Gregory Kiss \\ Kiss+Cathcart Architects \\ 44 Court St. $12^{\text {th }}$ floor \\ Brooklyn, New York 11201 \\ Doug Balcomb, Ph.D. \\ g.kiss@kisscathcart.com \\ National Renewable Energy Laboratory \\ 1617 Cole Blvd. \\ Golden, Colorado 80401-3393 \\ Doug_Balcomb@nrel.gov \\ Melinda Becker-Humphry \\ Smithsonian Institution \\ 955 L'Enfant Plaza, Suite 3230 \\ Washington, D.C. 20024 \\ humphm@opplp.si.edu
}

\begin{abstract}
A new version of the ENERGY-10 computer program simulates the performance of photovoltaic systems, in addition to a wide range of opportunities to improve energy efficiency in buildings. This paper describes two test cases in which the beta release of ENERGY-10 version 1.4 was used to evaluate energy efficiency and building-integrated photovoltaics (BIPV) for two Federal building projects: a $16,000-\mathrm{ft}^{2}(1,487$ $\mathrm{m}^{2}$ ) office and laboratory building at the Smithsonian Astrophysical Laboratory in Hilo, Hawaii, and housing for visiting scientists [three $1400-\mathrm{ft}^{2}\left(130 \mathrm{~m}^{2}\right)$ and three $1564-\mathrm{ft}^{2}$ $\left(145 \mathrm{~m}^{2}\right)$ houses] at the Smithsonian Environmental Research Center in Edgewater, Maryland. The paper describes the capabilities of the software, the method in which ENERGY-10 was used to assist in the design, and a synopsis of the results. The results indicate that ENERGY-10 is an effective tool for evaluating BIPV options very early in the building design process. By simulating both the building electrical load and simultaneous PV performance for each hour of the year, the ENERGY-10 program facilitates a highly accurate, integrated analysis.
\end{abstract}

\section{INTRODUCTION}

The U.S. Department of Energy (DOE) Federal Energy Management Program (FEMP) supports agencies in their efforts to make new Federal buildings energy efficient and to maximize the use of renewable energy. The ENERGY-10 computer program has proved useful in setting goals and evaluating performance in the design of small $\left(10,000 \mathrm{ft}^{2}\right.$ or less) Federal buildings. The DOE Office of Building Technology, State and Community Programs, the National Renewable Energy Laboratory (NREL), Lawrence Berkeley National Laboratory (LBNL), and the Sustainable Buildings Industry Council (SBIC) have released a beta test version of ENERGY-10-version 1.4. This new version now has the capability to evaluate grid-tied photovoltaic installations as well as energy efficiency opportunities in buildings.

\section{NOMENCLATURE}

Aspect ratio: East/west dimension divided by north/south dimension

Solar heat gain coefficient (SHGC): Fraction of incident solar power transferred through a window as heat and light 


\section{ENERGY-10 AND TRNSYS COMBINED}

ENERGY-10 is a software design tool for building energy analysis [1]. In version 1.4, a new feature simulates the performance of a photovoltaic (PV) system integrated into the envelope of a building. It allows the user to study hourly interactions between the building load and the PV array. The program distinguishes wall-integrated, roof-integrated, window-integrated, and standoff systems. The PV system description can include up to four building-integrated arrays and one standoff array, all fed through a single inverter. At present, only grid-connected systems (no battery storage) are modeled.

ENERGY-10 initially creates an "autobuild shoebox" based only on size (square footage), location, utility rates, type of heating and cooling system, and number of floors. The shoebox is useful for setting goals and strategizing before the design begins. As the design progresses, details are added and the shoebox is transformed into the evolving design. This provides many other capabilities to building designers, including making investigating the use of PV much easier and eliminating initial hurdles; providing comprehensive graphical output [2]; and having the ability to accommodate future technology, such as new PV products integrated into building elements or thin-film window coatings. The program integrates hourly analysis of thermal and electric systems; hourly schedules for lights, plug loads, etc.; hourly variable heating, ventilating, and air-conditioning (HVAC) loads responding to weather; hourly variable light dimming due to daylighting; and hourly PV system energy delivery [3].

The hour-by-hour simulation of PV performance in ENERGY10 uses the TRNSYS simulation program, written at the University of Wisconsin. ENERGY-10 creates inputs and a weather file for TRNSYS and reformats the hourly output for study within ENERGY-10. The hourly electrical load fed to TRNSYS is the result of the thermal simulation, accounting for all weather-driven effects and occupant schedules, including time-varying HVAC loads and light dimming due to daylighting. In a two-step process, PV electrical energy is not subtracted from the thermal energy balance of the outermost layer but can be approximated by reducing the absorptivity of the outer layer where the BIPV is located by the PV efficiency (typically 10\%).

Whereas synthetic loads have been used in other programs, the new PV capability helps ENERGY-10 users evaluate how a PV system will offset realistic building electrical loads. If the PV system is integrated into the building skin, there will be thermal effects that are accounted for by changes in the building description, which is passed to the ENERGY-10 thermal simulation engine. Thus, results produced by this tool show the overall consequences of building electrical load requirements before and after the PV system contribution, PV system output, and when and how much of the PV output is available to be sold back to the utility. These results are available as annual summaries and as typical monthly and hourly plots. Plots provide views of the 8,760 hours of data for 13 electrical variables that include disaggregated building loads (heating, cooling, lights, fan, plug loads) and PV system variables such as $\mathrm{PV}$ system output, $\mathrm{PV}$ to the building, and PV sellback.

The TRNSYS PV model [4] predicts the current-voltage (I-V) behavior of a flat-plate PV module, given the solar irradiance and ambient temperature. Arrays are defined as series-parallel connections of modules, with a tilt angle and orientation. The user can select detailed module descriptions from a library or define new module types. The PV balance-of-system is assumed to include an inverter operating as defined by a 10point conversion efficiency curve. A simple dispatch strategy is applied: building load is offset by PV output and any excess is counted as sellback to the grid.

\section{SMITHSONIAN ASTROPHYSICAL OBSERVATORY}

The Smithsonian Astrophysical Observatory (SAO) Base Facility will include about 16,000 usable square feet of electronics laboratories, offices, and support space in the University of Hawaii's Hilo Science Park. Figures 1 through 3 are illustrations of the concept design, dated January 2, 2001. Key assumptions consistent with standard ASHRAE 90.1 [5] were that lighting power is $1.78 \mathrm{~W} / \mathrm{ft}^{2}$; exterior walls are 6-in. steel frame; shear walls are 8-in. block; glazing is double-pane, aluminum frame with thermal break; floor-to-ceiling height is $14 \mathrm{ft}$ on both floors; air conditioning is Package Terminal Air Conditioning; and occupancy is 19 persons upstairs and 12 persons downstairs. Based on utility bills from Hawaii Electric Light Company for other Smithsonian facilities in the area, the energy cost was taken as $\$ 0.177 / \mathrm{kWh}$ and the demand cost as $\$ 5.740 / \mathrm{kW}$.

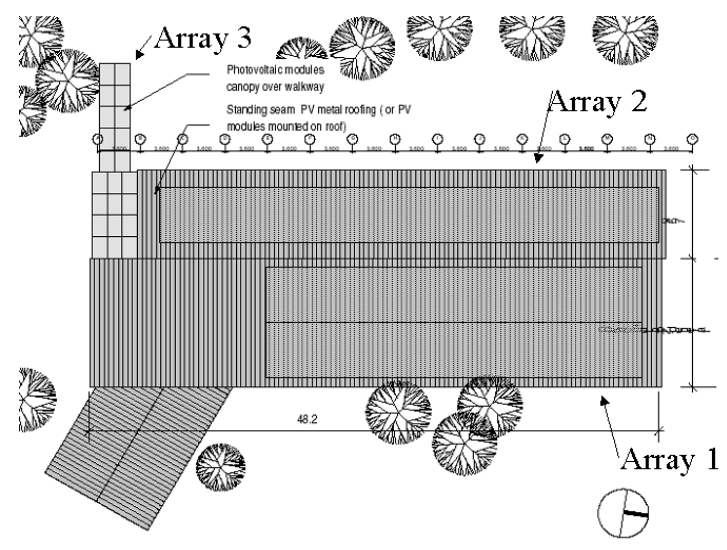

Figure 1. Plan view of SAO with PV integrated into standing-seam metal roof and walkway canopy. 


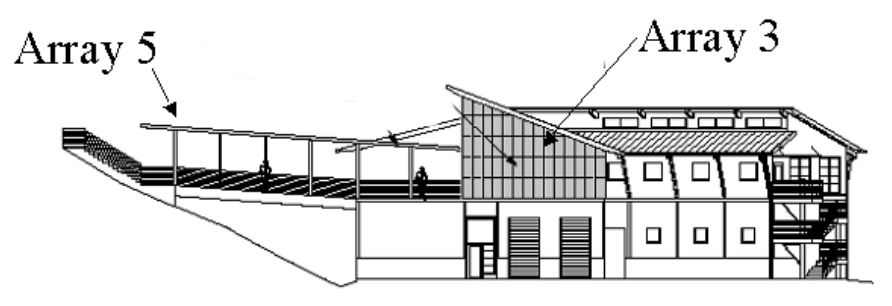

Figure 2. South elevation views of SAO with PV integrated into curtain wall glazing and walkway canopy.

Several recommendations to improve the energy efficiency of the building were evaluated both individually and in combination. The measures considered were these:

- Reduce installed lighting capacity from $1.78 \mathrm{~W} / \mathrm{ft}^{2}$ to $1.0 \mathrm{~W} / \mathrm{ft}^{2}$ through efficient equipment and architectural design of the lighting system.

- Modulate artificial lighting in response to available daylight through windows. Two control strategies were evaluated:

- Continuous dimming

- Three-step switching.

- Increase cooling system efficiency from energy efficiency rating (EER) 8.1 to EER 11.5.

- Use programmable thermostat to set up the cooling set temperature from $72^{\circ} \mathrm{F}\left(24^{\circ} \mathrm{C}\right)$ to $87^{\circ} \mathrm{F}\left(30^{\circ} \mathrm{C}\right)$ during unoccupied periods (setbacks from $5^{\circ} \mathrm{F}$ to $25^{\circ} \mathrm{F}$ were considered).

- Replace double-pane glazing [U $=0.49 \mathrm{Btu} / \mathrm{hrft}^{2 \circ} \mathrm{F}$ $\left(2.78 \mathrm{~W} / \mathrm{m}^{2 \circ} \mathrm{C}\right)$, SHGC $\left.=0.77\right]$ with selective double pane glazing $\left[\mathrm{U}=0.28 \mathrm{Btu} / \mathrm{hrft}^{2 \circ} \mathrm{F}\left(1.59 \mathrm{~W} / \mathrm{m}^{2 \circ} \mathrm{C}\right)\right.$, $\mathrm{SHGC}=0.37]$

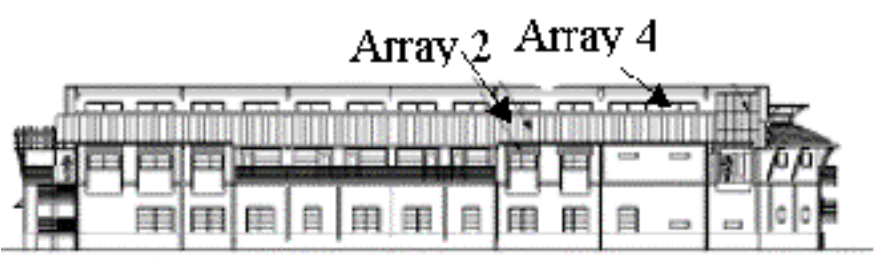

Figure 3. West elevation view of SAO with PV integrated into standing seam metal roof and curtain wall.

Taken together, these recommendations could reduce annual energy use from 1,563,001 kBtu/year $(458 \mathrm{MWh} /$ year $)$ at a cost of $\$ 88,585 /$ year to $970,576 \mathrm{kBtu} /$ year $(284 \mathrm{MWh} /$ year) at a cost of $\$ 55,222 /$ year. Energy use per square foot of floor area is reduced from 91.0 to $56.5 \mathrm{kBtu} / \mathrm{ft}^{2} /$ year (287 to 178 $\mathrm{kWh} / \mathrm{m}^{2} /$ year).

After the energy efficiency measures were incorporated, photovoltaics were considered to provide electric power.
Because of the uniform solar resource and high avoided cost of energy, Hawaii represents an excellent opportunity to demonstrate photovoltaics, which convert sunlight directly to electricity. Insulating value is not significant for the thin roof and window BIPV materials considered here. Photovoltaic devices would be integrated into architectural elements of the building, such as the roof, curtain wall, and walkway canopy:

- Array 1 and Array 2: The large expanse of roof facing east and west is the location for standing-seam metal roofing with Unisolar ASR128 modules. Each module is $16 \mathrm{in}$. wide (metal pan width) and $18.3 \mathrm{ft}$ long. Array 1 consists of two rows of modules on the wider east roof for a capacity of $22.5 \mathrm{~kW}$. Array 2 consists of one row on the west roof with a capacity of $15.1 \mathrm{~kW}$. Each module is $48 \mathrm{~V}$ dc (open circuit) and they can be wired in series in groups of 12 to produce $576 \mathrm{~V}$ dc (open circuit). The operating voltage would be $33 \mathrm{~V}$ dc per module for $396 \mathrm{~V} \mathrm{dc}$ operating voltage.

- Array 3 and Array 4: The south (Array 3) and westfacing (Array 4) glass curtain walls are the location for ASE 30-DG-UT panels with partial transmissivity. The glass panels, $1.2 \mathrm{~m}$ long by $0.6 \mathrm{~m}$ wide, have a power output of $27 \mathrm{~W}$ each. Each has an open-circuit voltage of $60 \mathrm{~V} \mathrm{dc}$, and they can be wired in series in groups of 10. Array 3 is $1.1 \mathrm{~kW}$ and Array 4 is 0.4 $\mathrm{kW}$.

- Array 5: The walkway canopy is covered with ASE 300 modules $1.28 \mathrm{~m}$ wide and $1.89 \mathrm{~m}$ long, each rated at $300 \mathrm{~W}$. Each has an open-circuit voltage of $60 \mathrm{~V} \mathrm{dc}$; they can be wired in series in groups of 10 .

Table 1. ENERGY-10 report showing detail on each of the 5 BIPV arrays on the SAO.

\begin{tabular}{|l|c|}
\hline Total PV Array Area, $\mathrm{ft}^{2} / \mathrm{m}^{2}$ & 8264 / 768 \\
\hline Total PV Rated Output, $\mathrm{kW}$ & 45.4 \\
\hline Total Inverter Rated Capacity, $\mathrm{kW}$ & 105 \\
\hline & \\
\hline Array 1 & \\
\hline BIPV Type / Rated Power, $\mathrm{kW}$ & Roof-Integrated / 22.5 \\
\hline No. of Modules & 176 \\
\hline Area ( $\mathrm{ft}^{2}$ ) /Azimuth /Tilt & 4334 / 90 / 20 \\
\hline & \\
\hline Array 2 & Roof-Integrated / 15.1 \\
\hline BIPV Type / Rated Power, $\mathrm{kW}$ & 118 \\
\hline No. of Modules & 2906 / 270 / 20 \\
\hline Area (ft ${ }^{2}$ /Azimuth/Tilt & \\
\hline & \\
\hline Array 3 & Wall-Integrated / 1.1 \\
\hline BIPV Type / Rated Power, $\mathrm{kW}$ & \\
\hline
\end{tabular}




\begin{tabular}{|c|c|}
\hline No. of Modules & 43 \\
\hline Area $\left(\mathrm{ft}^{2}\right) /$ Azimuth/Tilt & $333 / 180 / 90$ \\
\hline \multicolumn{2}{|l|}{ Array 4} \\
\hline BIPV Type / Rated Power, kW & Wall-Integrated / 0.4 \\
\hline No. of Modules & 15 \\
\hline Area $\left(\mathrm{ft}^{2}\right) /$ Azimuth /Tilt & $116 / 270 / 90$ \\
\hline \multicolumn{2}{|l|}{\begin{tabular}{|l} 
Stand-Off (Array 5) \\
\end{tabular}} \\
\hline BIPV Type / Rated Power, kW & Stand-Off / 6.6 \\
\hline No. of Modules & 22 \\
\hline Area $\left(\mathrm{ft}^{2}\right) /$ Azimuth/Tilt & $574 / 0 / 0$ \\
\hline \multicolumn{2}{|l|}{ PV Simulation Results: } \\
\hline \multicolumn{2}{|l|}{ 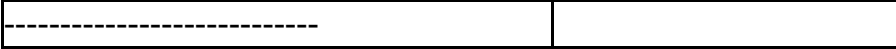 } \\
\hline PV System Output, kWh & 51361 \\
\hline PV Sellback, kWh & 411 \\
\hline \multicolumn{2}{|c|}{$\begin{array}{l}\text { PV Output of Each Array before Power Conditioning Losses } \\
\text { (inverter inefficiency) }\end{array}$} \\
\hline Array $1, \mathrm{kWh}$ & 25076 \\
\hline Array $2, \mathrm{kWh}$ & 16736 \\
\hline Array $3, \mathrm{kWh}$ & 723 \\
\hline Array 4, kWh & 261 \\
\hline Array 5, kWh & 10309 \\
\hline Total, kWh & 53105 \\
\hline Total Bldg Electric Load, kWh & 284279 \\
\hline Supplied by PV, kWh & 49305 \\
\hline Supplied by Grid, kWh & 234973 \\
\hline Peak PV Net Output, kW, time & Feb $28 \quad 12: 00$ \\
\hline Peak PV Output to Bldg, kW, time & $23.4 \quad$ Feb 28 $12: 00$ \\
\hline Peak PV Sellback to Grid, kW, time & $4.1 \quad$ Oct $5 \quad 13: 00$ \\
\hline Bldg Peak Elec., kW, time & $\begin{array}{lll}77.0 & \text { Sep } 9 & 8: 00 \\
\end{array}$ \\
\hline Bldg Peak PV Coincident Output, kW & 13.8 \\
\hline Bldg Net Elec. Peak, kW, time & $65.0 \quad 9 / 16 \quad 7: 00$ \\
\hline
\end{tabular}

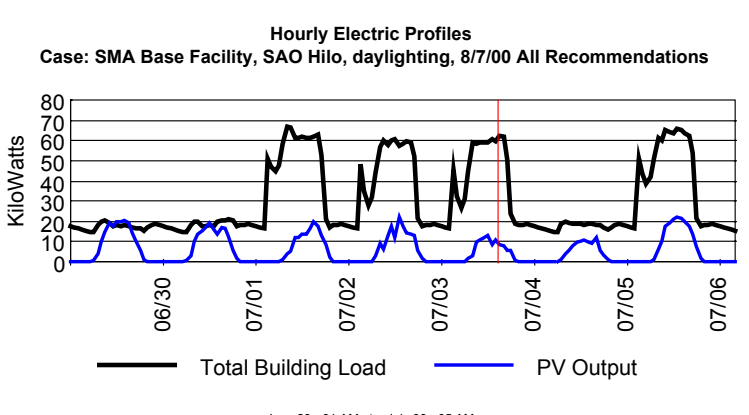

Figure 4. ENERGY-10 report showing PV output and total building electrical load for the first week in July.

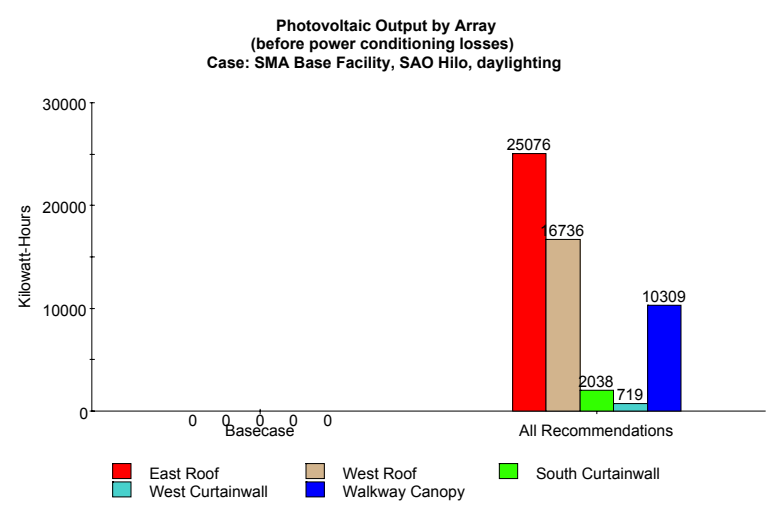

Figure 5. ENERGY-10 report showing annual DC energy delivery of each of the five BIPV arrays on the SAO.

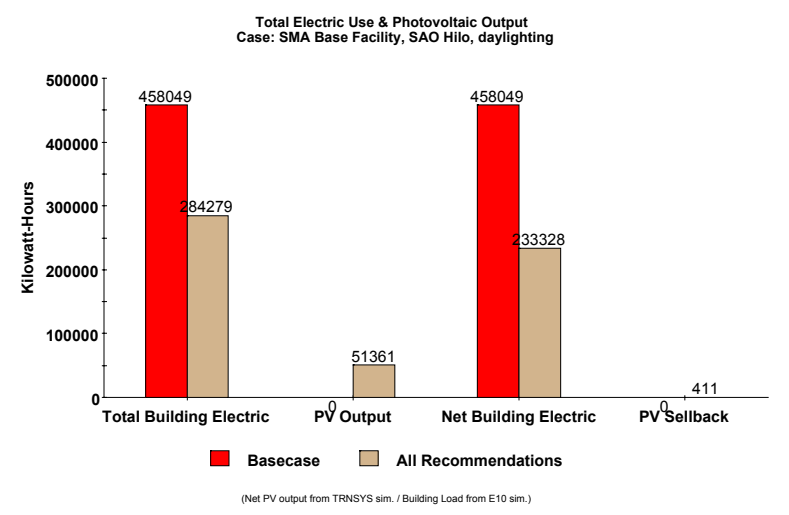

Figure 6. ENERGY-10 report showing annual energy use of SAO basecase, energy efficiency improvements, and BIPV savings.

\section{SMITHSONIAN ENVIRONMENTAL RESEARCH CENTER}

The Smithsonian Environmental Research Center (SERC) is a 4200-acre environmental research facility located on Chesapeake Bay in Edgewater, Maryland. SERC's interdisciplinary research applies short-term and long-term studies to examine the ecological landscapes of linked ecosystems, especially those impacted by human activities. 
The institute's mission requires that impacts due to site operations be minimized, a justification for considering PV. The overall project proposes constructing a visiting scientist housing complex consisting of three two-story houses, three one-story accessible houses, a laundry building, and a seminar/conference building. Each housing unit consists of two bedroom/bathroom modules and a shared kitchen/eating area and living room space. The fully developed housing complex will provide accommodations for up to 24 researchers. SERC is committed to providing as much clean, reliable power from renewable sources as is economically feasible. Since a large component of the mission at SERC is to educate the thousands of visitors each year, an educational opportunity about renewable energy exists. For brevity, only the analysis of the two-story housing units is presented [6].

The basecase (reference case) is a hypothetical case based on the requirements of ASHRAE 90.2-1993, Energy Efficient Design of New Low-Rise Residential Buildings [7]. Some key assumptions include a ceiling R-value of $30 \mathrm{ft}^{2} \mathrm{hr}^{\circ} \mathrm{F} / \mathrm{Btu}(0.19$ $\left.\mathrm{W} / \mathrm{m}^{2 \circ} \mathrm{C}\right)$; wall R-value of $15.8 \mathrm{ft}^{2} \mathrm{hr}{ }^{\circ} \mathrm{F} / \mathrm{Btu}\left(0.36 \mathrm{~W} / \mathrm{m}^{2 \circ} \mathrm{C}\right)$; floor R-value of $21.3 \mathrm{ft}^{2} \mathrm{hr}{ }^{\circ} \mathrm{F} / \mathrm{Btu}\left(0.27 \mathrm{~W} / \mathrm{m}^{2 \circ} \mathrm{C}\right)$; fenestration $\mathrm{R}$-value of $2 \mathrm{ft}^{2} \mathrm{hr}^{\circ} \mathrm{F} / \mathrm{Btu}\left(2.8 \mathrm{~W} / \mathrm{m}^{2 \circ} \mathrm{C}\right)$; and an air-conditioning EER of 7.6, minimum. Lighting power is assumed at $1.2 \mathrm{~W} / \mathrm{ft}^{2}$ $\left(13 \mathrm{~W} / \mathrm{m}^{2}\right)$. Exterior walls are $2 \times 4$ wood frame with insulated sheathing and wood siding. Windows are double-pane, aluminum frame with thermal break. Floor-to-ceiling height is $9 \mathrm{ft}(2.7 \mathrm{~m})$. The floor plan is a simple rectangle with an aspect ratio of 0.75 . Windows are equally distributed on all exterior walls. Air conditioning and heating are provided by a split system with electric furnace, and the ducts run through the unvented crawlspace. Occupancy is assumed at 400 $\mathrm{ft}^{2} /$ person. The current (2001) electric rate from Delmarva Power \& Light utility company, averaging $\$ 0.092 / \mathrm{kWh}$, is used in the analysis. Natural gas is not available at the site.

Results of the ENERGY-10 simulation for the 1,400 $\mathrm{ft}^{2}(130$ $\mathrm{m}^{2}$ ) one-story basecase building indicate that the peak cooling load is 4 tons; the peak electrical load is $14.9 \mathrm{~kW}$; and annual energy use intensity averages $65.7 \mathrm{kBtu} / \mathrm{ft}^{2} /$ year (207 $\mathrm{kWh} / \mathrm{m}^{2} /$ year). Basecase energy use results in an annual cost of $\$ 2,478 /$ year.

The schematic design incorporates several features to improve energy performance over the basecase:

- House orientation: Largely east and west, with the large façades and windows facing north and south to reduce summertime solar gains and admit winter sun

- Insulation: The 6-in. wall provides R-17.7 insulation, a higher R-value than the $15.8 \mathrm{ft}^{2} \mathrm{hr}^{\circ} \mathrm{F} / \mathrm{Btu}(0.36$ $\mathrm{W} / \mathrm{m}^{2}{ }^{\circ} \mathrm{C}$ ) prescribed by code
- Wood frames and low-e glass: Used to reduce the window heat loss coefficient from $\mathrm{U}=0.49$ to $\mathrm{U}=$ $0.28 \mathrm{Btu} / \mathrm{ft}^{2} \mathrm{hr}{ }^{\circ} \mathrm{F}\left(1 / 6 \mathrm{~W} / \mathrm{m}^{2 \circ} \mathrm{C}\right)$

- Energy-efficient lighting equipment: Specification of fluorescents where possible is estimated to reduce interior lighting from $280 \mathrm{~W}$ to $210 \mathrm{~W}$, and exterior lighting from $56 \mathrm{~W}$ to $42 \mathrm{~W}$

- Daylighting: Provided in almost every room, mitigating the daytime use of electric light

- Programmable thermostats

- Whole-house fan

- Insulated hot water piping

- Low-flow showerheads

- Energy-efficient appliances.

The following measures were also recommended to further improve the performance of the schematic design:

- Ground-source heat pump

- Solar water heating

- Drain water heat recovery

- Structural insulated panel construction

- Infiltration measures.

ENERGY-10 cannot currently model some of these recommended measures; in those cases, the savings are either not included in the estimate (insulated water piping, energyefficient appliances, whole-house fan), or are calculated by hand and estimated by reducing the associated load (groundsource heat pump [8], low-flow shower heads, drain water heat recovery [9], solar water heating).

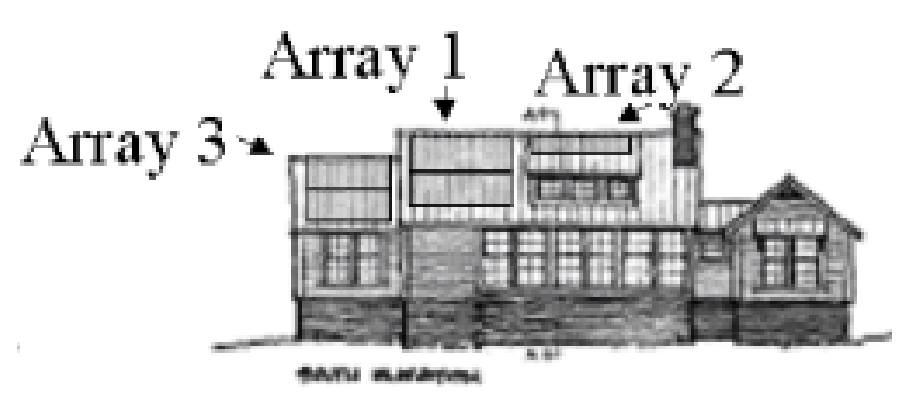

Figure 7. Schematic design of SERC one-story housing unit by Architrave PC with three standing-seam BIPV arrays added to south-facing roof.

Photovoltaics are integrated into the building roof to further reduce the load. The site is wooded, and some trees would have to be removed to mitigate shading. The south-facing roof is the location for standing-seam metal roofing with Unisolar ASR-64 modules [10]. Each module is 16 in. $(0.4 \mathrm{~m})$ wide (metal pan width) and $9.5 \mathrm{ft}(2.9 \mathrm{~m})$ long. There are two rows of modules on the living room roof and the bedroom roof, and 
one row of modules on the roof of the clerestory section in the living room. The insulating value of the BIPV materials is not considered. Each module is $24 \mathrm{~V}$ dc (open circuit), and they can be wired in series in groups of two to produce $48 \mathrm{~V}$ dc (open circuit). The operating voltage would be $17 \mathrm{~V}$ dc per module for $34 \mathrm{~V}$ dc operating voltage.

Table 2. ENERGY-10 report showing detail of the three BIPV arrays on the SERC one-story housing units.

\begin{tabular}{|c|c|}
\hline Total PV Array Area, $\mathrm{ft}^{2} / \mathrm{m}^{2}$ & $612 / 57$ \\
\hline Total PV Rated Output, kW & 3.1 \\
\hline $\begin{array}{l}\text { Total PV Annual AC Output, } \\
\text { kWh }\end{array}$ & $\begin{array}{l}3688 \text { (3195 to house, } \\
493 \text { to grid) }\end{array}$ \\
\hline Annual Building Load, kWh & 23194 \\
\hline Annual Supplied by Grid, kWh & 19999 \\
\hline \multicolumn{2}{|l|}{ Living Room South Roof } \\
\hline BIPV Type / Rated Power, kW & $\begin{array}{l}\text { Standing seam, roof- } \\
\text { integrated, ASR-64 } \\
\text { modules, } 64 \mathrm{~W} \text { each, } \\
\text { two rows } / 1.3 \mathrm{~kW}\end{array}$ \\
\hline No. of Modules & 20 \\
\hline Area $\left(\mathrm{ft}^{2}\right) /$ Azimuth/Tilt & $255 / 0 / 3$ \\
\hline Annual DC Output, kWh & 1402 \\
\hline \multicolumn{2}{|l|}{ Living Room Clerestory Roof } \\
\hline BIPV Type / Rated Power, kW & $\begin{array}{l}\text { Standing seam, roof- } \\
\text { integrated, } \quad \text { ASR-64 } \\
\text { modules, } 64 \mathrm{~W} \text { each, } \\
\text { one row / } 0.6 \mathrm{~kW}\end{array}$ \\
\hline No. of Modules & 10 \\
\hline Area $\left(\mathrm{ft}^{2}\right) /$ Azimuth/Tilt & $128 / 0 / 18$ \\
\hline Annual DC Output, kWh & 881 \\
\hline \multicolumn{2}{|l|}{ West Bedroom South Roof } \\
\hline BIPV Type / Rated Power, kW & $\begin{array}{l}\text { Standing seam, roof- } \\
\text { integrated, } \\
\text { modules, } 64 \mathrm{~W} \text { each, } \\
\text { two rows } / 1.2 \mathrm{~kW}\end{array}$ \\
\hline No. of Modules & 18 \\
\hline Area $\left(\mathrm{ft}^{2}\right) /$ Azimuth/Tilt & $230 / 90 / 38$ \\
\hline Annual DC Output, kWh & 1644 \\
\hline
\end{tabular}

Of a total building electric load of 23,194 kWh per year, 3,195 kWh would be supplied by PV and 19,999 kWh would be supplied by the electric utility. Thus, solar would provide $14 \%$ of the building's power requirements. The peak PV net output is $2.1 \mathrm{~kW}$, on March 19 at 11:00 am. The building electrical peak is $18.9 \mathrm{~kW}$ on January 31 at 3:00 am. At that time, the PV system is not producing power to reduce the peak load. Figure 8 shows annual energy use of a code-compliant basecase, the schematic design for the house, a case with all efficiency measures included, and a case with BIPV added.

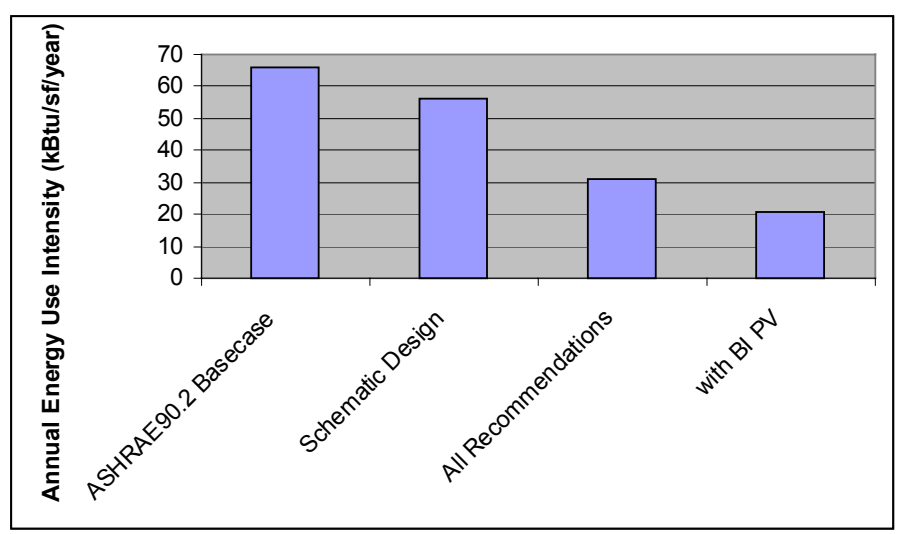

Figure 8. Annual utility energy use intensity (Btu/ $\mathrm{ft}^{2} /$ year) of basecase, schematic design, all efficiency measures, and BIPV for one-story SERC housing unit.

\section{CONCLUSIONS}

In these two case studies, ENERGY-10 was used to facilitate the evaluation of energy efficiency measures and photovoltaics measures very early in the design process. Making it easy to consider these measures increases awareness among architects and designers. As the design develops, ENERGY-10 results identify and justify cost-effective measures, resulting in optimal building designs and high customer satisfaction. The estimate of annual energy delivery for the five systems on the SAO by ENERGY-10 is $4.6 \%$ higher than that of the widely accepted PV F-Chart method [11], as shown in Figure 9.

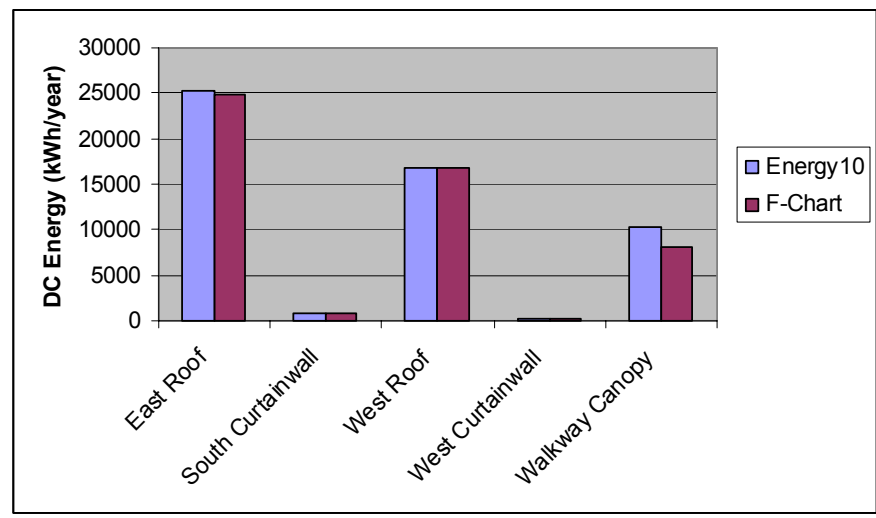

Figure 9. Comparison of annual de energy delivery for five arrays on the SAO, as predicted by both ENERGY-10 and F-Chart.

For both of these facilities, the Smithsonian Institution has reasons to consider photovoltaics beyond simple cost effectiveness. Nevertheless, budgets are strained, and the final designs may include photovoltaics only in smaller demonstration systems. For example, a recommended alternative design for the SAO incorporating BIPV only over the entry canopy is illustrated in Figure 10. 


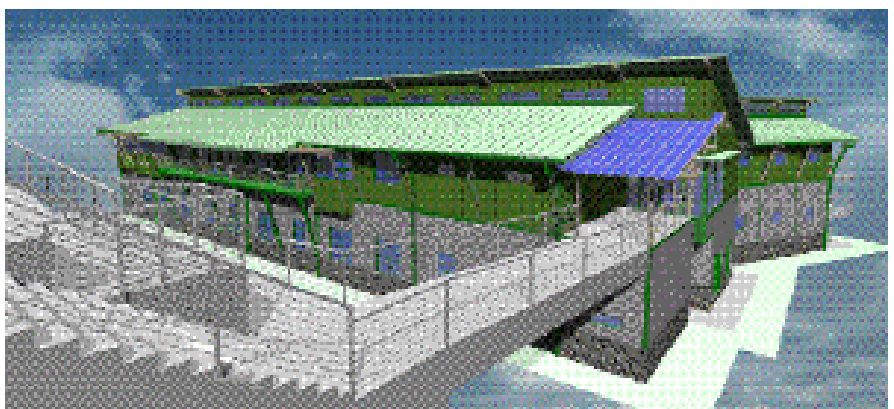

Figure 10. Rendering of SAO featuring small BIPV entry canopy to maximize demonstration benefits at reasonable cost (Source: Kiss+Cathcart Architects PC).

\section{ACKNOWLEDGMENTS}

The ENERGY-10 computer program was developed by the DOE Office of Building Technology, State and Community Programs, NREL, LBNL, and SBIC. The DOE Federal Energy Management Program (FEMP), Beth Shearer, Director, sponsored this analysis in support of the Smithsonian Institution Office of the Physical Plant. The FEMP Design Assistance and Renewable Energy Programs are managed by Shawn Herrera and Anne Crawley.

\section{REFERENCES}

[1] Balcomb, J.D. 1997. "Energy-10: 1997 A Design Tool for Buildings." Building Simulation '97, International Building Performance Simulation Association, Prague, September.

[2] Christensen, C. 1984 Digital and Color Energy Maps for Graphic Display of Hourly Data. SERI/TP-2532461. Available from NTIS: DE85000526. Golden, $\mathrm{CO}$, September.

[3] Wilcox, B. A., J. R. Barnaby, and P. W. Niles. 1992. CNE Users Manual. Berkeley Solar Group, Oakland, CA.

[4] Klein, S. A. 1996. TRNSYS - A Transient Simulation Program. Solar Energy Laboratory, University of Wisconsin, Madison.

[5] American Society of Heating, Refrigerating and AirConditioning Engineers, Inc. 1989. ASHRAE 90.1, Energy-Efficient Design of New Buildings Except Low-Rise Residential Buildings. ASHRAE, Atlanta, GA.

[6] French, J., Hoffman, R., and Pompetti, P. 1994. Facilities Master Plan: Smithsonian Environmental Research Center. Ballinger Company, Philadelphia, PA, December.
[7] American Society of Heating, Refrigerating and AirConditioning Engineers, Inc. 1993. ASHRAE 90.2, Energy-Efficient Design of New Low-Rise Residential Buildings. ASHRAE, Atlanta, GA.

[8] American Society of Heating, Refrigerating, and AirConditioning Engineers, Inc. 1997. ASHRAE Handbook - Fundamentals (SI ed.). ASHRAE, Atlanta, GA.

[9] Vasile, C. 2001. Residential waste water heatrecovery system: GFX. CADDET Energy Efficiency Series. December. Fact sheet accessed on July 12, 2001, on the World Wide Web: http://www.caddetee.org/newsdesk/nw497_05.htm .

[10] United Solar Systems Corporation. 2001. Uni-Solar Roofing Systems Architectural Standing Seam Panels. (n.d.). Information retrieved on July 20, 2001, from the World Wide Web: http://ovonic.com/unitedsolar/ roofingsystemarchitech.html.

[11]PV F-Chart. 2000. Software available from F-Chart Software, Box 4042, Madison, WI 53711. 


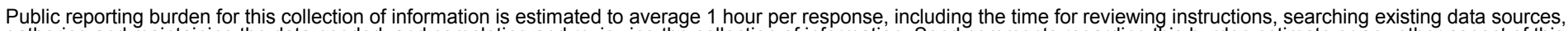

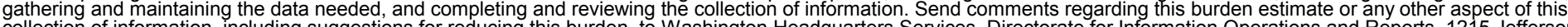
Davis Highway, Suite 1204, Arlington, VA 22202-4302, and to the Office of Management and Budget, Paperwork Reduction Project (0704-0188), Washington, DC 20503.
1. AGENCY USE ONLY (Leave blank)
2. REPORT DATE
March 2002
3. REPORT TYPE AND DATES COVERED
Conference Paper

4. TITLE AND SUBTITLE

Analyzing Two Federal Building-Integrated Photovoltaic Projects Using ENERGY-10 Simulations
5. FUNDING NUMBERS

FE01.3015

6. AUTHOR(S)

Andy Walker, Doug Balcomb, NREL; Norm Weaver; Gregory Kiss; and Melinda BeckerHumphry

7. PERFORMING ORGANIZATION NAME(S) AND ADDRESS(ES)

8. PERFORMING ORGANIZATION REPORT NUMBER

National Renewable Energy Laboratory

9. SPONSORING/MONITORING AGENCY NAME(S) AND ADDRESS(ES)

National Renewable Energy Laboratory

1617 Cole Blvd.

Golden, CO 80401-3393

10. SPONSORING/MONITORING AGENCY REPORT NUMBER

NREL/CP-710-31310

11. SUPPLEMENTARY NOTES

NREL Technical Monitor:

12a. DISTRIBUTION/AVAILABILITY STATEMENT

National Technical Information Service

U.S. Department of Commerce

5285 Port Royal Road

Springfield, VA 22161

13. ABSTRACT (Maximum 200 words)

A new version of the ENERGY-10 computer program simulates the performance of photovoltaic systems in addition to presenting a wide range of opportunities for users to improve the energy efficiency of building designs. This paper describes two test cases in which the beta release of ENERGY-10 version 1.4 was used to evaluate energy efficiency and buildingintegrated PV for two Federal building projects: an office and laboratory building at the Smithsonian Astrophysical Laboratory in Hawaii, and housing for visiting scientists at the Smithsonian Environmental Research Center in Maryland. By simulating both the building electrical load and simultaneous PV performance for each hour of the year, the ENERGY-10 program facilitates a highly accurate, integrated analysis.

\begin{tabular}{|c|c|c|c|}
\hline \multirow{2}{*}{\multicolumn{3}{|c|}{$\begin{array}{l}\text { 14. SUBJECT TERMS } \\
\text { Solar energy; computer simulations }\end{array}$}} & $\begin{array}{l}\text { 15. NUMBER OF PAGES } \\
7\end{array}$ \\
\hline & & & 16. PRICE CODE \\
\hline $\begin{array}{l}\text { 17. SECURITY CLASSIFICATION } \\
\text { OF REPORT } \\
\text { Unclassified }\end{array}$ & $\begin{array}{l}\text { 18. SECURITY CLASSIFICATION } \\
\text { OF THIS PAGE } \\
\text { Unclassified }\end{array}$ & $\begin{array}{l}\text { 19. SECURITY CLASSIFICATION } \\
\text { OF ABSTRACT } \\
\text { Unclassified }\end{array}$ & $\begin{array}{l}\text { 20. LIMITATION OF ABSTRACT } \\
\text { UL }\end{array}$ \\
\hline
\end{tabular}

